DOI: 10.30519/ahtr.915136

Advances in Hospitality and Tourism Research (AHTR)

\title{
INVESTIGATING WHICH SERVICES ARE EFFECTIVE ON RECOMMENDATION OF THE AIRLINE COMPANIES
}

\author{
Seden DOĞAN ${ }^{1}$ \\ Faculty of Tourism, Ondokuz Mayis University, Turkey \\ ORCID: 0000-0001-8547-7702 \\ Emrah ÖZKUL \\ Faculty of Tourism, Kocaeli University, Turkey \\ ORCID: 0000-0002-7938-6916 \\ Gamze KAYA \\ Institute of Social Sciences, Mersin University, Turkey \\ ORCID: 0000-0002-7634-3101
}

\begin{abstract}
This study aimed to determine which services provided by airlines had an influence on recommendations. The authors collected passenger scores from the years between 2014 to 2019 concerning the top 10 airline companies of 2019 from the website www.AirlineQuality.com, which is the site most commonly used by passengers to evaluate airline companies and airports worldwide. In total, we analyzed 5512 ratings. Binary logistic regression was applied to test the hypothesis. According to the results, the most influential criterion is value for money. The second most important criterion is customer relations. Seat and cabin space and meals and beverages follow customer relations. The least important criterion related to recommendations is inflight entertainment. Previous studies were conducted using surveys. The present study used online ratings to determine airline attributes with the most and least influence on recommendations.
\end{abstract}

Article History

Received 13 April 2021

Revised 26 September 2021

Accepted 5 October 2021

Published online 14 Oct. 2021

\section{Keywords}

airline companies

passenger evaluation

online ratings

online reviews

recommendation

\section{INTRODUCTION}

Businesses operating in the airline industry, which has accelerated with the introduction of private airlines since the early 1980s (Kos Koklic et al., 2017), are now facing difficulties such as increasing costs, fluctuations in demand, and quality expectations (Baker, 2013). In addition to these difficulties, the

\footnotetext{
${ }^{1}$ Address correspondence to Seden Doğan (Ph.D.), Department of Tourism Guidance, Faculty of Tourism, Ondokuz Mayis University, Samsun, Turkey. E-mail: seden.dogan@omu.edu.tr
} 
intense competition in the sector reveals the importance of passengers' perception of service quality. Understanding the factors that affect passengers' preference for an airline is an indicator that enables companies to take advantage of the competition (Lin \& Huang, 2015; Namukasa, 2013). The companies that understand these factors may provide more suitable goods and services to satisfy passengers and make them loyal. Eventually, loyal passengers will be an important advantage in terms of competition. Although price is one of the most important of these factors, research shows that service quality is also a vital factor (Bubalo \& Gaggero, 2015; Kim \& Lee, 2011; Suki, 2014). Tangible features such as furnishing and seat comfort and intangible features such as security, cleaning, and customer service, are also important in quality perception of the provided service.

The authors observed that the academic research about the products and services offered by the airline companies was mostly conducted with SERVQUAL-based surveys (Aydın \& Yıldırım, 2012; Başfırıncı \& Mitra, 2015; Chou et al., 2011; Du et al., 2012; Farooq et al., 2018; Ganiyu, 2017; Hapsari et al., 2016; Huang, 2009; Hussain et al., 2015; Hussain, 2016; Jiang \& Zhang, 2016; Kağnıcıŏglu \& Özdemir, 2016; Leong et al., 2015; Pakdil \& Aydin, 2007). As another observation, travel review and rating sites focus mostly on accommodation businesses (Banerjee \& Chua, 2016; Bayram, 2017; Cezar \& Öğüt, 2016; Doğan, 2017; Hu \& Chen, 2016; Min et al., 2014; Neirotti et al., 2016; Pacheco, 2016; Raguseo et al., 2017; Sparks et al., 2016) and food and beverage businesses (Bertan, 2016; Cheng \& Ho, 2015; Dalgıç et al., 2016; Doğan et al., 2016; Erdem \& Yay, 2017; Eren \& Çelik, 2017; Kim et al., 2016; Taştan \& Kizılcık, 2017; Zhu et al., 2018). More people use these types of websites to share their experiences and opinions about companies by writing reviews or scoring different criteria. The influence and the importance of other people's opinions on purchase, re-purchase, and recommendation behavior have been investigated and proved by many scholars (Chakraborty \& Bhat, 2018; Cheong et al., 2020; Filieri et al., 2018; Jalilvand \& Samiei, 2012; Jimenez \& Mendoza, 2013; Kudeshia \& Kumar, 2017; Lin et al., 2011; Thomas et al., 2019; Zhang et al., 2014).

It was seen that research related to online reviews and ratings for airlines was very limited (Bogicevic et al., 2017; Brochado et al., 2019; Güngör et al., 2019; İbiş \& Batman, 2016; Lacic et al., 2016; Siering et al., 2018a; Stamolampros et al., 2018; Yao et al., 2015). Using online reviews and ratings as data might help us to understand passengers' general overview regarding the airlines' services. It also might be possible to determine the most important factor(s) influencing passengers' airline recommendations. In this context, the purpose of the present study was to determine the effect 
of airlines' ratings according to five criteria on recommendations for the top 10 airlines in 2019 selected by the website www.WorldAirlineAwards.com, which has been announcing the top 100 airlines of the year based on the passengers' votes since 2012 (World Airline Awards, 2020). Even though the website asks the users if they recommend the airline to others, scores given to the specific criteria may have a significant effect on the recommendation, because these scores represent the level of satisfaction. The authors claim that if the passengers are satisfied with the specific criteria related to the goods and services provided by the airlines, they will recommend the airline.

\section{LITERATURE REVIEW}

\section{Online Customer Reviews and Ratings}

According to the report entitled "Digital in 2020" prepared by the research company We Are Social, as of January 2020 the number of Internet users worldwide reached 4.54 billion. This figure corresponds to more than half of the world's population (59\%). In the same report, it is stated that the number of social media users worldwide constitutes 3.8 billion people which is equal to $49 \%$ of the world's population (We Are Social, 2020). Consumers share their experiences with any product or service on the Internet. These sharing platforms, where word-of-mouth communication takes place electronically, are online customer commenting and rating websites (Siering et al., 2018a). These online customer comments and evaluations make up the content of the website, consisting of the opinions and ideas of the customer experiencing any goods or services. These comments and assessments are considered a reliable source of data and provide information and recommendations on goods and services from a customer perspective (Rose \& Blodgett, 2016). These comments and assessments give consumers insight into real users' experiences but are also seen as an important monitoring tool for businesses (Lee et al., 2011). Research reveals that 24,000 new comments or ratings per minute are found on these sites. Some $85 \%$ of Internet users rely on these comments and scores. One-third of travelers write reviews, score goods and services on these websites, and regularly visit them. At this point, it is seen that these websites are the most effective source of information for the purchasing decision (Eslami et al., 2018; Gretzel \& Yoo, 2017; Guo et al., 2017; Hong et al., 2017; Siering et al., 2018b; Stringam \& Gerdes, 2010).

Online consumer reviews and ratings are particularly important because the quality of tourist goods or services cannot be understood 
without experiencing them (Book et al., 2018; Doğan et al., 2016; Güngör et al., 2019; Park \& Nicolau, 2015; Xie et al., 2017). According to the "Travel Consumption Report" published by Deloitte (2015) based on a survey of 40509 people, $42 \%$ of consumer review commentary sites, $31 \%$ review the website of the travel company, and $21 \%$ review the website of online travel companies. Travelers tend to prefer high-rated accommodation, transport, travel, and food and beverage businesses (Schuckert et al., 2016). On the other hand, it is stated that the comments and scores on these websites contain more up to date, more detailed, and more accurate information (Stringam et al., 2010). These reviews and ratings can be more helpful and insightful compared to traditional information sources (Mellinas et al., 2019), and they are recognized as the second most frequently used information source by Internet users (Bigne et al., 2020). Moreover, scholars claim that online ratings are relatively objective, considered numerical evidence of different attributes of a service or product, and reflect the extent of consumers' satisfaction (Hong \& Pittman, 2020; Zhu et al., 2019). These ratings, which are scored on a scale between one and five, represent a summary of a consumer's opinion about a product or service that might encourage other consumers to make a purchase decision (Hong \& Pittman, 2020), help them to gather information about different attributes in a utilitarian nature, and are used to evaluate companies' products and services (Thuy Tran et al., 2019a). Thuy Tran et al. (2019b) also found that online ratings have a significant effect on continuance intention and presented "the positive perceived usefulness and attitude towards the continuous usage of the relevant company" (p. 315). Moreover, the reviews and ratings on these websites provide various types and amounts of data for scholars. These data can be used with either quantitative or qualitative techniques to gain insights into consumers' decision-making process and companies' performance (Phillips et al., 2020).

The main websites that include travelers' reviews and ratings on travel are TripAdvisor, Yahoo Travel, Igougo, HolidayCheck, and Lonely Planet (Browning et al., 2013). The websites where airlines are evaluated include Airline Ratings, Airline Quality, TripAdvisor, Flight-Report, and Trust Pilot.

\section{Airline Services and Recommendation}

According to the product classification formulated by the United Nations, the transportation sector within the service industry is based on the displacement of humans or human belongings. It is defined as the sector that enables the transportation of people and manufactured goods or 
services from one place to another (Doğan \& Beller Dikmen, 2018a, p. 758; 2018b, p. 25).

Air transportation, which took on a commercial dimension after World War II, is the realization of transportation, as mentioned above, by air vehicles. Apart from revenue-based transport, flights for individual purposes are also considered within this scope. Air transport is considered a sector that is influenced by national security and public interests and that has an international aspect compared to other sectors. Globalization, technological developments, prosperity, the development of international trade, the development of airline transport networks, and increased tourism opportunities led to rapid growth in air transport in the 20th century (Bahar, 2018, p. 26).

The Service Quality Scale (SERVQUAL), developed by Parasuraman et al. (1991, 1994a, 1994b), has been used by many researchers to date. In the research conducted on airline companies, it was determined that the dimensions of the scale were concrete features, interest/relevance, reliability, intervention to problems, and safety (Wang et al., 2011, p. 433). The tangibles among these dimensions are physical assets such as footrests, the distance between seats, magazines, food and beverage types, pillows, blankets, sleeping goggles, cleaning of airplanes and toilets, in-flight entertainment (such as film, music, and game facilities), employee behavior as a measure of service quality, the technical components of the aircraft, and the offices of the airline company (Kim \& Lee, 2011; Nadiri et al., 2008; Suki, 2014). Ali et al. (2015) specified the general condition of the aircraft, the quality of food and beverage services, seat comfort, and general cleaning factors among the physical features of the airline.

Furthermore, different factors have been identified in studies conducted by various researchers to determine passenger satisfaction with airlines. Gourdin (1988) stated that price, security, and punctuality are the three dimensions of airline service quality. Ostrowski et al. (1993) noted the comfort of seats, food and drink, and the punctuality of flights. Truitt and Haynes (1994) stated that the cleanliness of seats, flight procedure, punctuality of flights, handling of food and beverages, and dealing with passenger complaints are essential factors. Nadiri et al. (2008) determined that the physical characteristics of the airline are essential factors for passenger satisfaction and intention to buy again. $\mathrm{Ng}$ et al. (2011) mentioned flight services such as the attendants and cabin supervisor, while Kim and Lee (2011) stated that creating fast solutions with particular features has an impact on passenger satisfaction. Wu and Cheng (2013) 
highlighted the importance of eleven factors: cleanliness, problem-solving skills, general management, personnel expertise, comfort, safety and security, physical features, waiting time, convenience, value, and access to information. Suki (2014) determined that the particular characteristics of the airline had a positive and direct significant effect on passenger satisfaction, while Farooq et al. (2018) listed the service provided by the staff and the particular characteristics of the airline.

Additionally, if the concrete features of the airline and value for money are sufficient to ensure passenger satisfaction, the passenger will continue to choose the airline and recommend it through social networks even if the ticket prices of another company are more favorable (Ali et al., 2015; An \& Noh, 2009; Bejou \& Palmer, 1998; Chiou \& Chen, 2010; Kos Koklic et al., 2017; Mohsan et al., 2011; Namukasa, 2013; Park et al., 2004; Suki, 2014). Brochado et al. (2019) conducted content analysis on a total of 1200 reviews for six different airline companies on TripAdvisor and concluded that the essential services are those offered by the airline during the flight (in-flight entertainment, food, drinks, etc.) in terms of value for money.

On the other hand, loyalty, which is defined as "the continuous repurchase and use of a product or service in the future with deep commitment" and which has a direct positive relationship with customer satisfaction, is examined as behavioral loyalty and attitude loyalty. Behavioral loyalty includes not the only repurchase but also less price sensitivity, a better alternative, and recommending it to others (Akamavi et al., 2015; Amin et al., 2012; Jahanshahi et al., 2011; Kasiri et al., 2017; Kim et al., 2013; Liu et al., 2011, Noyan \& Gölbaşı Şimşek, 2014; Nyadzayo \& Khajehzadeh, 2016; Pan et al., 2012; Rahman \& Ramli, 2016; Srivastava \& Kaul, 2016; Zakaria et al., 2014). An important indicator of behavioral loyalty is recommending a satisfactory good or service (Bandyopadhyay \& Martell, 2007; Cheng, 2011). Passengers who are satisfied with the airline's services are more likely to spread positive opinions about the airline company and recommend it (Shah et al., 2020; Suki, 2014).

As mentioned above, different factors can impact passengers' satisfaction leading to behavioral loyalty, which is their recommendation of the airline company. The authors aimed to identify the level of the impact of the factors that are provided on the Airline Quality website by using passengers' online scores. In this context, the hypotheses were determined as follows: 
$\mathrm{H}_{1 \mathrm{a}}$ : The scores that show the satisfaction level of the passenger given for the overall value-for-money criterion have an impact on their recommendation of the airline.

$\mathrm{H}_{1 \mathrm{~b}}$ : The scores that show the satisfaction level of the passenger given for the seat space and cabin space criterion have an impact on their recommendation of the airline.

$\mathrm{H}_{1}$ : The scores that show the satisfaction level of the passenger given for the customer services criterion have an impact on their recommendation of the airline.

$\mathrm{H}_{1 \mathrm{~d}}$ : The scores that show the satisfaction level of the passenger given for the in-flight entertainment criterion have an impact on their recommendation of the airline.

$\mathrm{H}_{1}$ : The scores that show the satisfaction level of the passenger given for the meals and beverages criterion have an impact on their recommendation of the airline.

The effect of independent variables on recommendation was analyzed within this scope.

\section{METHODOLOGY}

The research question was determined as "What is the level of effect of the scores given to various criteria on the same website for the recommendation of the airline for the top 10 airlines of 2019 on www.AirlineQuality.com?" The passengers create a profile for themselves on this website to evaluate the airline companies' attributes and services by writing detailed reviews or by giving scores between 1 and 5 for different criteria provided by the website. These criteria were overall value for money paid, seat space and cabin space, customer services, in-flight entertainment, meals and beverages, ground services, and Wi-Fi connectivity. Because there were too many missing values for the last two criteria, which means many users did not rate them, these criteria were excluded from the analysis.

\section{Sample of the Study}

There are different airline review and rating websites on the Internet such as AirlineRatings.com, AirlineQuality.com, and Flight-Report.com. AirlineRatings.com contains limited numbers of ratings and FlightReport.com does not provide users' ratings; it provides only reviews. In this case, AirlineQuality.com was used as the data source because it is the sub- 
initiative of Skytrax, the oldest airline evaluation system, established in 1989. The website provides reviews and ratings regarding the services of airlines, airports, and lounges. Passengers have been sharing their opinions about airlines and scoring the services since 2010 .

Since all the scores on that website are difficult to collect due to time constraints, we chose convenience sampling as a non-random sampling method. In convenience sampling it is the researcher's judgments that determine a non-random sampling method in which the sample is to be selected from the universe. With inconvenience sampling, data are collected from the universe in the easiest, fastest, and most economical way. In this respect, the authors determined the scores given to various criteria between January 1, 2014 and December 31, 2019, for the top 10 airlines in 2019. The airlines are listed below (World Airline Awards, 2019):

1. Qatar Airways

2. Cathay Pacific

3. Singapore Airlines

4. Emirates

5. All Nippon Airways

6. Lufthansa

7. Qantas

8. Thai Airways

9. Ethiad Airways

10. EVA Air

\section{Data Collection Method and Tool}

The data were collected manually between August 25 and September 5, 2020. The oldest score for the criteria of the above airlines was given in 2014. An evaluation form was created to collect the data manually. Information about the user's year of travel, month, class of travel, and ratings for the criteria were recorded on these forms. In total, 5784 scores for ten airline companies were collected, but some users did not score one or more criteria, so missing data were excluded from the analysis and a total of 5512 scores were analyzed.

\section{Variables}

Accordingly, the dependent variable was whether users recommend the airline or not, and the independent variables were value for money, seat and cabin space, customer service, in-flight entertainment, meals, and beverages. The dependent variable was identified as recommended and not 
recommended. In this context, the non-referral behavior, which is no recommendation, was coded as 0 (zero) and the referral behavior, which is recommendation, as 1 (one). The independent variables value for money, seat space and in-cabin space, customer service, in-flight entertainment, and food and beverages were scored between 1 and 5 .

\section{Data Analysis}

Binary logistic regression analysis was used to test the hypotheses determined for the study since the dependent variable had two categories as "yes" and "no". Logistic regression analysis, also known as the logit model, is used in studies in the field of medicine. However, it is an advanced regression method that has been used in social sciences in recent years. Logistic regression analysis is used when the dependent variable consists of two- or multi-level categorical data, and the cause-and-effect relationships between the dependent variable and independent variables are examined (Arabameri et al., 2019).

Logistic regression analysis is a type of regression analysis, but also it is a differential analysis technique. In this context, there are three important differences from regression analysis:

- While the dependent variable is numerical in regression analysis, it is a discrete value in logistic regression analysis.

- In regression analysis, the value of the dependent variable is estimated and, in logistic regression, the probability of one of the dependent variables is estimated.

- In regression analysis, it is necessary to have multiple normal distributions of independent variables. At the same time, no conditions are required for the distribution of independent variables in order to apply logistic regression.

Binary logistic regression analysis is based on the probability ratio. The probability ratio compares the likelihood that an event will occur and the likelihood that it will not. In the present study, the non-referral behavior was 0 (null) and the referral behavior was 1 (one). The binary logistic regression model describes the relationship between a binary outcome variable and one or more predictor variables (Fagerland \& Hosmer, 2012:447). 


\section{RESULTS}

As mentioned above, binary logistic regression analysis was performed to test the hypotheses of the study. The first test to be performed when performing this analysis is the Hosmer-Lemeshow test. The goodness of fit of the model is a measure of the effectiveness of the model created to explain the dependent variable. The Hosmer-Lemeshow test was used as a measure of goodness of fit of the model. Chi-square was 17.902 and the p-value was 0.472 . The significance level of the Hosmer-Lemeshow test was higher than 0.05 , indicating that the model is appropriate for the data (Cavagnaro et al., 2016, p. 139; Force et al., 2018, p. 436; Zaidan, 2017, p. 257). The p-value is significant since it is $0.295>0.05$. Thus, the model is suitable for performing logistic regression analysis.

Table 1. Classification Table

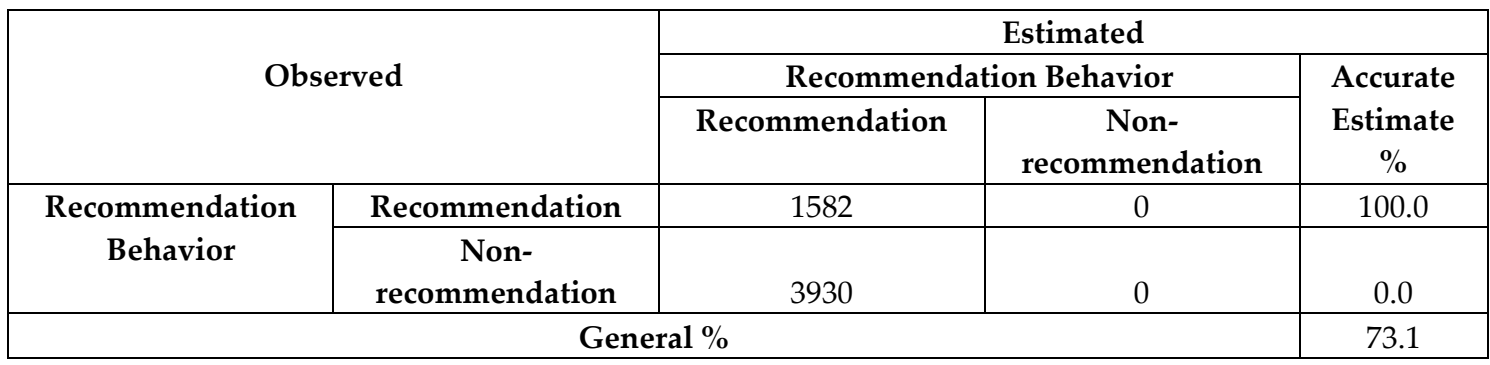

According to Table 2, $100 \%$ of the model was able to predict the recommendation behavior of the users correctly. In general, the correct classification rate of the model is $73.1 \%$. After determining the suitability of the proposed model for logistic regression analysis according to the data obtained from the participants, it was necessary to look at whether the independent variables were significant in explaining the dependent variable. The omnibus test, which measures the significance of model coefficients, was performed to test the difference of parameters from zero.

Table 2. Omnibus Test of Model Coefficients (Significance of Coefficients)

\begin{tabular}{|llllc|}
\hline Step 1 & & Chi-Square & sd & Significance (p) \\
\hline & Step & 4318.098 & 5 & 0.000 \\
& Block & 4318.098 & 5 & 0.000 \\
& Model & 4318.098 & 5 & 0.000 \\
\hline
\end{tabular}

Significance values are less than $1 \%$; logistic regression coefficients are not equal to zero at the same time. Thus, the model is statistically significant at 1\% level (Wan Daud et al., 2011, p. 211).

After finding the model coefficients were significant, it was necessary to look at the percentage of changes in the dependent variable 
explained by the independent variables proposed in the model. According to Table 4, the increase or decrease in the dependent variable in the model is $54.3 \%$ according to Cox-Snell and $77.8 \%$ according to Nagelkerke. In other words, $77.8 \%$ of users' behavior regarding their recommendation of the airline can be explained by the independent variables in the model (value for money, seat space and cabin space, customer service, in-flight entertainment, and meals and beverages). Therefore, it can be concluded that $22.2 \%$ of different independent variables affect the recommendation or non-recommendation behavior.

Table 3. Model Summary Table

\begin{tabular}{|cclc|}
\hline Step & -2 Log Likelihood & Cox and Snell R Square & Nagelkerke R Square \\
\hline 1 & 2290.271 & 0.543 & 0.778 \\
\hline
\end{tabular}

The last table to look at in logistic regression analysis is the parameter estimation table. Table 4 shows the parameter estimation obtained from the model proposed to measure the effects of independent variables on the behavior of recommending or not recommending the airline as a dependent variable.

Table 4. Parameter Estimation Table

\begin{tabular}{lcccccc}
\hline & $\begin{array}{c}(\boldsymbol{\beta}) \mathbf{( R e g} \\
\text { Coef.) }\end{array}$ & $\begin{array}{c}\text { S.E. (Standard } \\
\text { Error) }\end{array}$ & $\begin{array}{c}\text { Wald } \\
\text { Statistics }\end{array}$ & sd & $\begin{array}{c}\text { Significance } \\
(\mathbf{p})\end{array}$ & $\begin{array}{c}\text { Odds Ratio } \\
\text { Exp }(\boldsymbol{\beta})\end{array}$ \\
\hline Overall Value for Money & 1.408 & 0.062 & 507.552 & 1 & $\mathbf{0 . 0 0 0}$ & 4.087 \\
Seat and Cabin Space & 0.481 & 0.052 & 84.499 & 1 & $\mathbf{0 . 0 0 0}$ & 1.617 \\
Customer Relations & 0.558 & 0.049 & 130.324 & 1 & $\mathbf{0 . 0 0 0}$ & 1.747 \\
In-flight Entertainment & 0.257 & 0.052 & 24.647 & 1 & $\mathbf{0 . 0 0 0}$ & 1.292 \\
Meals and Beverages & 0.368 & 0.051 & 51.802 & 1 & $\mathbf{0 . 0 0 0}$ & 1.446 \\
Constant & -9.677 & 0.307 & 991.138 & 1 & $\mathbf{0 . 0 0 0}$ & 0.000 \\
\hline
\end{tabular}

The $\beta$ values (regression coefficient) in Table 4 show the effective coefficient of each independent variable. Wald statistics are used to test whether each independent variable is significant in the model. If the Wald statistic exceeds 2, it is an indication that the variable is significant. The values in the Exp column in the table show the odds ratios of the independent variables. Exp shows the change in the level of superiority if the other variables in the model are kept constant, and the relevant variable will be increased by 1 unit. To summarize the interpretation of the odds ratio briefly: if the odds ratio is greater than 1 , then $A$ and $B$ are associated (correlated); conversely, if the odds ratio is less than 1, then A and B are negatively correlated, and the presence of one event reduces the odds of the other event (Park, 2013, p. 161; Sarkar \& Midi, 2010, p. 481; Tessema Zewude \& Meskele Ashine, 2016, p. 6; Zhang et al., 2013, p. 124). 
According to Table 4, the independent variables (value for money, seat space and cabin space, customer service, in-flight entertainment, and meals and beverages) have an impact on whether the airline is recommended. At this point, the hypotheses $\mathrm{H}_{1 a}, \mathrm{H}_{1 \mathrm{~b}}, \mathrm{H}_{1 \mathrm{c}}, \mathrm{H}_{1 \mathrm{~d}}$, and $\mathrm{H}_{1 \mathrm{e}}$ determined within the scope of the study were supported.

According to the table, overall value for money is the most important criterion for recommendation. The second most important criterion is customer relations. Seat and cabin space and meals and beverages follow customer relations. The least effective criterion influencing the recommendation is in-flight entertainment. According to these results, overall value for money had the most significant impact on recommending the airline among the five criteria and the in-flight entertainment had the lowest impact. This result supports the literature, which is discussed below.

\section{DISCUSSION AND CONCLUSION}

In the present study, we evaluated the services offered by airline companies through online consumer ratings. For this assessment, we used data from www.AirlineQuality.com and analyzed the companies selected as the 10 best airlines. Attempts were made to answer the question of whether they affect the airline's recommendation given according to different criteria. The criteria included in the hypotheses developed according to the theoretical background are value for money, space for the seat area and cabin, customer service, in-flight entertainment services, and food and beverages.

As a result of the logistic regression analysis, the developed hypotheses were supported. In other words, when in-flight entertainment and food and beverage facilities are not satisfactory, when there is a high price compared to the service received, when the seat space and in-cabin facilities cannot be raised to the desired level, and when customer service is insufficient passengers tend not to recommend the airline. As a result of the study, we determined that overall value for money was the criterion with the most significant impact on the recommendation of the airline. This result supports Gures et al.'s (2014) research, as they found that the price and value for money were the most critical factors influencing recommendations. In our study, $73 \%$ percent of the passengers flew in economy class. Economy class ticket rates are cheaper than other flight classes. It seems that other services are more important than the price for the passengers who rated the attributes and services provided by flight companies that were the sample of the present study. Similarly, Forgas et 
al. (2010) found that value for money for the airline is a factor that affects satisfaction and recommendation behavior, especially for low-priced airlines.

The second more effective criterion was customer relations. This result also supports the previous literature. Kos Koklic et al. (2017) found that quality of customer service positively affected customer satisfaction and hence the recommendation of the firm. Calisir et al. (2016) determined that the passengers who were satisfied with the quality of the service offered by the airline made positive comments about the company and recommended the company to others as a result of their research with 237 passengers that participated on the Frankfurt-Istanbul flight. Milioti et al. (2015) found that the essential factors for passengers were the reliability and ready-to-help personnel during the flight and the in-flight entertainment facilities were relatively less important. Vlachos and Lin (2014) found that in-flight and out-of-flight personnel services were influential on the recommendation of the airline company in their survey of airlines operating in China. Archana and Subha (2012) surveyed 270 passengers flying with Indian Airlines and determined that the most critical factor affecting the perceived service quality was in-flight entertainment. Al-Refaie et al. (2014) and Kim and Lee (2011) emphasized that the staff's ability to deal with problems and complaints has an impact on passenger satisfaction and recommendation behavior.

The third factor influencing recommendations is seat and cabin space. The fourth important factor for the passengers is meals and beverages, and the least influential criterion for recommendation is in-flight entertainment. These results also support the previous research referred to above.

Theoretically, the present study showed that the data obtained from an online rating website could be used as a source to analyze passengers' satisfaction level and behavioral loyalty. These ratings might be more reliable that the surveys conducted by airline companies themselves because the passengers are more comfortable as they might choose to rate anonymously. The results supported several previous studies mentioned above. If the passengers are satisfied with the goods and services provided by the airline company, they are more likely give higher ratings on the related websites and recommend the company to others.

Individuals may prefer to express their opinions, feelings, and experiences on the Internet and social media platforms rather than calling the company and talking to an employee, because they might be more 
comfortable writing a review than talking to an employee. In addition, they can do it whenever and wherever they want. There will be no pressure, no concern about time, and no inconvenience of going to the company's office or making a phone call. In this sense, these online posts by passengers must be regarded as a valuable source by companies and they must monitor the comments and ratings shared on the Internet. It should be helpful to reach out to those who write negative comments and give low ratings and to strive to ensure their satisfaction. Airline companies can send feedback directly to their passengers by sending an online questionnaire after the flight. This might help to prevent online complaints and negative electronic word-of-mouth.

The present study was carried out by considering the data on the Internet. The number of websites providing these data is enormous, there is no standard evaluation form offered to consumers on these websites, and the data are updated frequently due to the nature of the Internet. The authors assumed that since the users who comment on airline companies on the relevant website and score various criteria differ in terms of demographic characteristics, the status of evaluating the airline companies was also different. Users who prefer any airline for transportation take their flight before commenting on the airline or rating various criteria and use the website www.AirlineQuality.com to comment and rate the various criteria. Comments and ratings on the website are published as they are, without any corrections or changes.

As with many other studies, this one also had limitations. First, the authors included only the ratings on the website www.AirlineQuality.com in the study and for the airlines selected as the top 10 airlines of the years between 2014 and 2019. Second, the scores given to various criteria on the same website were included in the study. Additionally, with COVID-19, which started with the report on December 31, 2019 and spread rapidly in 2020, air travel has decreased significantly. According to IATA reports, RPKs (revenue passenger kilometers, where the number of passengers and wages are calculated) were expected to decrease by approximately $40 \%$ with a revenue loss of US\$ 252 billion in 2020 (Gössling et al., 2020; IATA, 2020). The decisions to be taken by the World Health Organization and the World Tourism Organization and tourism countries on this issue remain uncertain. COVID-19 was not mentioned during the period (2014-2019) when the data related to this research were collected. Therefore, the researchers chose the variables in the study independently from this pandemic. 
Future studies may investigate some other variables' impacts. Moreover, it is predicted that the policies or practices such as ecofriendliness, green business, and sustainability implemented by airline companies will affect the evaluation criteria of studies to be carried out. More data can be obtained from different online rating websites for the same airline companies and comparative studies can be conducted. Furthermore, demographical differences can be included in the analyses and passengers who have different demographical characteristics can be compared as well.

\section{REFERENCES}

Akamavi, R. K, Mohamed, E., Pellmann, K., \& Xu, Y. (2015). Key determinants of passenger loyalty in the low-cost airline business. Tourism Management, 46, 528-545.

Al-Refaie, A., Bata, N., Eteiwi, D., \& Jalham I. (2014). Examining factors that affect passenger's overall satisfaction and loyalty: Evidence from Jordan Airport. Jordan Journal of Mechanical and Industrial Engineering, 8(2), 94-101.

Ali, F., Dey, B. L., \& Filieri, R. (2015). An assessment of service quality and resulting customer satisfaction in Pakistan international airlines: Findings from foreigners and overseas Pakistani customer. International Journal of Quality E Reliability Management, 32(5), 486-502.

Amin, S. M., Ungku Ahmad, U. N., \& Hui, L. S. (2012). Factors contributing to customer loyalty towards telecommunication service provider. Procedia - Social and Behavioral Sciences, 40, 282-286.

An, M., \& Noh. Y. (2009). Airline Customer satisfaction and loyalty: Impact of in-flight service quality. Service Business, 3(3), 293-307.

Arabameri, A., Pradhan, B., \& Lombardo, L. (2019). Comparative assessment using boosted regression trees, binary logistic regression, frequency ratio and numerical risk factor for gully erosion susceptibility modelling. Catena, 183,104223.

Archana, R., \& Subha, M. V. (2012). A Study on Service Quality and Passenger Satisfaction on Indian Airlines. International Journal of Multidisciplinary Research, 2(2), 50-63.

Aydın, K., \& Yıldırım, S. (2012). The measurement of service quality with SERVQUAL for different domestic airline firms in Turkey. Serbian Journal of Management, 7(2), 219-230.

Bahar, E. (2018). Development of airline management in Turkey. Arel University, Journal of Economy, Management and Social Research, 3(1), 25-36.

Baker, D. (2013). Service quality and customer satisfaction in the airline industry: A comparison between legacy airlines and low-cost airlines. American Journal of Tourism Research, 2(1), 6777.

Bandyopadhyay, S., \& Martell, M. (2007). Does attitudinal loyalty influence behavioral loyalty? A theoretical and empirical study. Journal of Retailing and Consumer Services, 14, 35-44.

Banerjee, S., \& Chua, A. Y. K. (2016). In search of patterns among travellers' hotel ratings in Tripadvisor. Tourism Management, 53, 125-131.

Başfırınc1, Ç., \& Mitra, A. (2015). A cross cultural investigation of airlines service quality through integration of SERVQUAL and the Kano model. Journal of Air Transport Management, 42, 239248.

Bayram, M. (2017). Consumers' perceptions of İstanbul restaurants: Evaluation of satisfaction determinants. Journal of Tourism and Gastronomy Studies, 5(4), 142-154.

Bejou, D., \& Palmer, A. (1998). Service failure and loyalty: An exploratory empirical study of airline customers. Journal of Services Marketing, 12(1), 7-22.

Bertan, S. (2016). The evaluation of Michelin Star restaurants. Journal of Human Sciences, 13(2), 32213230.

Bigne, E., William, E., \& Soria-Olivas, E. (2020). Similarity and consistency in hotel online ratings across platforms. Journal of Travel Research, 59(4), 742-758. 
Bogicevic, V., Yang, W., Bujisic, M., \& Bilgihan, A. (2017). Visual data mining: Analysis of airline service quality attributes. Journal of Quality Assurance in Hospitality $\mathcal{E}$ Tourism, 18(4), 509-530.

Book L. A., Tanford, S., Montgomery, R., \& Love, C. (2018). Online traveler reviews as social influence: Price is no longer king. Journal of Hospitality $\mathcal{E}$ Tourism Research, 42(3), 445-475.

Brochado, A., Rita, P., Oliveira, C., \& Oliveira, F. (2019). Airline passengers' perceptions of service quality: Themes in online reviews. International Journal of Contemporary Hospitality Management, 31(2), 855-873.

Browning V., Fung So K. K., \& Sparks B. (2013). The influence of online reviews on consumers' attributions of service quality and control for service standards in hotels. Journal of Travel and Tourism Marketing, 30(1-2), 23-40.

Bubalo, B., \& Gaggero, A. A. (2015). Low-cost carrier competition and airline service quality in Europe. Transport Policy, 43, 23-31.

Calisir, N., Basak, E., \& Calisir, F. (2016). Key drivers of passenger loyalty: A case of FrankfurtIstanbul Flights. Journal of Air Transport Management, 53, 211-217.

Cavagnaro, E., Staffieri, S., \& Huisman, T. (2016). Fun, animal welfare or community development? Understanding young tourists' preferences for a wildlife tourism package. Research in Hospitality Management, 6(2), 135-144.

Cezar, A., \& Öğüt, H. (2016). Analyzing conversion rates in online hotel booking: The role of customer reviews, recommendations and rank order in search listings. International Journal of Contemporary Hospitality Management, 28(2), 286-304.

Chakraborty, U., \& Bhat, S. (2018). The effects of credible online reviews on brand equity dimensions and its consequence on consumer behavior. Journal of Promotion Management, 24(1), 57-82.

Cheng, Y. H., \& Ho, H. Y. (2015). Social influence's impact on reader perceptions of online reviews. Journal of Business Research, 68(4), 883-887.

Cheng, S. (2011). Comparisons of competing models between attitudinal loyalty and behavioral loyalty. International Journal of Business and Social Sciences, 2(10), 149-166.

Cheong, J. W., Muthaly, S., Kuppusamy, M., \& Han, C. (2020). The study of online reviews and its relationship to online purchase intention for electronic products among the millennials in Malaysia. Asia Pacific Journal of Marketing and Logistics, 32(7),1519-38.

Chiou, Y., \& Chen, Y. (2010). Factors Influencing the intentions of passengers regarding full service and low-cost carriers: A note. Journal of Air Transport Management, 16, 226-228.

Chou, C. C., Liu, L. J., Huang, S. F., Yin, J. M., \& Han, T. Z. (2011). An evaluation of airline service quality using the fuzzy weighted SERVQUAL method. Applied Soft Computing, 11, 21172128.

Dalgıç, A., Güler, O., \& Birdir, K. (2016). Analysing restaurant complaints available at tripadvisor.com: A study on local food restaurants located in Mersin and Hatay. Journal of Tourism and Gastronomy Studies, 4(1), 153-173.

Deloitte (2015). Travel Consumer 2015: Engaging the Empowered Holidaymaker. Retrieved in July 11, 2018, from https://www2.deloitte.com/content/dam/Deloitte/pe/Documents/strategy/deloitte-uktravel-consumer-2015.pdf.

Doğan, Z., \& Beller Dikmen, B. (2018a). Comparison of transportation sector and types of transportation in Turkey. Journal of International Social Research, 11(56), 758-770.

Doğan, Z., \& Beller Dikmen, B. (2018b). Monitoring of Costs incurred due to the service supply of enterprises operating in the transportation sector. Niğde Ömer Halisdemir University, Journal of Economics and Administrative Sciences, 11(2), 24-39.

Doğan, S. (2017). A Study in Aksaray province on assessment of scoring and online comments on hotels. Aksaray University, Journal of Economics and Administrative Sciences, 9(3), 27-36.

Doğan, S., Yücel Güngör, M., \& Tanrısevdi, A. (2016). A content analysis of online consumer reviews: A case study on food and beverage enterprises in Kuşadası. International Refereed Journal of Marketing and Market Researches, Autumn Winter(9), 1-22.

Du, C., Ejem, E., \& Ezenwa, A. (2012). Evaluation of service quality of Nigerian Airline using Servqual model. Journal of Hospitality Management and Tourism, 3(6), 117-125.

Erdem, Ö., \& Yay, Ö. (2017). Evaluation of customer complaints in Tripadvisor: Case of Antalya. Journal of Tourism and Gastronomy Studies, 5(4), 227-249. 
Eren, R., \& Çelik, M. (2017). Online gastronomy image: Content analysis of Tripadvisor comments of Turkey restaurant. Tourism Academic Journal, 4(2), 121-138.

Eslami, S. P., Ghasemaghaei, M., \& Hassanein, K. (2018). Which online reviews do consumers find most helpful? A multi-method investigation. Decision Support Systems, 113, 32-42.

Fagerland, M.W., \& Hosmer, D.W. (2012). A generalized Hosmer-Lemeshow goodness-of-fit test for multinomial logistic regression models. The Stata Journal, 12(3), 447-453.

Farooq, M. S., Salam, M., Fayolle, A., Jaafar, N., \& Ayupp, K. (2018). Impact of service quality on customer satisfaction in Malaysia Airlines: A PLS-SEM approach. Journal of Air Transport Management, 67, 169-180.

Filieri, R., McLeay, F., Tsui, B., Lin, Z. (2018). Consumer Perceptions of information helpfulness and determinants of purchase intention in online consumer reviews of services. Information $\mathcal{E}$ Management, 55(8), 956-970.

Force, A., Manuel-Navarrete, D., \& Benessaiah, K. (2018). Tourism and transitions toward sustainability: Developing tourists' pro-sustainability agency. Sustainability Science, 13, 431445.

Forgas, S., Moliner, M. A., Sanchez, J., \& Palau, R. (2010). Antecedents of airline passenger loyalty: Low-cost versus traditional airlines. Journal of Air Transport Management, 16, 229-233.

Ganiyu, R. A. (2017). Customer satisfaction and loyalty: A study of interrelationships and effects in Nigerian domestic airline industry. Oradea Journal of Business and Economics, II(1), 7-20.

Gourdin, K. (1988). Bringing quality back to commercial travel. Transportation Journal, 27(3), 23-29.

Gössling S., Scott D., \& Hall, M. C. (2020). Pandemics, tourism and global change: A rapid assessment of COVID-19. Journal of Sustainable Tourism, 29(1), 1-20.

Gretzel, U., \& Yoo, K-H. (2017). Social media in hospitality and tourism. In S. K. Dixit (Ed.), The Routledge Handbook of Consumer Behaviour in Hospitality and Tourism, (pp. 339-346), London: Routledge.

Guo, Y., Barnes, S. J., \& Jia, Q. (2017). Mining meaning from online ratings and reviews: tourist satisfaction analysis using latent Dirichlet allocation. Tourism Management, 59, 467-483.

Gures, N., Arslan, S., \& Yucel Tun, S. (2014). Customer expectation, satisfaction and loyalty relationship in Turkish airline industry. International Journal of Marketing Studies, 6(1), 66-74.

Güngör, O., Yücel Güngör, M., \& Doğan, S. (2019). Examining the evaluations in TripAdvisor about Turkish Airlines. Journal of Tourism Theory and Research, 5(2), 282-291.

Hapsari, R., Clemes, M., \& Dean, D. (2016). The mediating role of perceived value on the relationship between service quality and customer satisfaction: Evidence from Indonesian Airline Passengers. Procedia Economics and Finance, 35, 388-395.

Hong, S., \& Pittman, M. (2020). eWOM anatomy of online product reviews: interaction effects of review number, valence, and star ratings on perceived credibility. International Journal of Advertising, 39(7), 892-920.

Hong, H., Xu, D., Wang, A., \& Fan. W. (2017). Understanding the determinants of online review helpfulness: a meta-analytic investigation. Decision Support Systems, 102, 1-11.

Hu, Y. H., \& Chen, K. (2016). Predicting hotel review helpfulness: the impact of review visibility, and interaction between hotel stars and review ratings. International Journal of Information Management, 36(6), 929-944.

Huang, Y. K. (2009). The effect of airline service quality on passengers' behavioural intentions using SERVQUAL scores: A Taiwan case study. Journal of the Eastern Asia Society for Transportation Studies, 8, 2330-2343.

Hussain, R. (2016). The mediating role of customer satisfaction: evidence from the airline industry. Asia Pacific Journal of Marketing and Logistics, 28(2), 234-255.

Hussain, R., Al Nasser, A., \& Hussain, Y. K. (2015). Service quality and customer satisfaction of a UAE-based airline: an empirical investigation. Journal of Air Transport Management, 42, 167175.

IATA. (2020). The International Air Transport Association (IATA). Retrieved in June 17, 2021, from www.iata.org.

İbiş, S., \& Batman, O. (2016). Analysis of Customer Complaints for Airline Companies. Paper presented at 3rd International Congress of Tourism \& Management Researches, 20th-22nd May 2016, Mersin, Turkey. 
Jahanshahi, A. A., Gashti, M. A. H., Mordamadi, S. A., \& Khaksar, S. M. S. (2011). Study the effects of customer service and product quality on customer satisfaction and loyalty. International Journal of Humanities and Social Science, 1(7), 253-260.

Jalilvand, M., \& Samiei, N. (2012). The effect of electronic word of mouth on brand image and purchase intentions: an empirical study in the automobile industry in Iran. Marketing Intelligence $\mathcal{E}$ Planning, 30(4), 460-476.

Jiang, H., \& Zhang, Y. (2016). An investigation of service quality, customer satisfaction and loyalty in China's airline market. Journal of Air Transport Management, 57, 80-88.

Jimenez, F. R., \& Mendoza, N. A. (2013). Too popular to ignore: the influence of online reviews on purchase intentions of search and experience products. Journal of Interactive Marketing, 27(3), 226-235.

Kağnıcıŏlu, C. H., \& Özdemir, E. (2016). Service quality perception in service sector: an application in airline check-in services. Journal of Management, Marketing and Logistics, 3(2), 156-162.

Kasiri, L. A., Guan Cheng, K. T., Sambasivan, M., \& Sidin, S. M. (2017). Integration of standardization and customization: impact on service quality, customer satisfaction, and loyalty. Journal of Retailing and Consumer Services, 35, 91-97.

Kim, W. G., Li, J., \& Brymer, R. A. (2016). The impact of social media reviews on restaurant performance: the moderating role of excellence certificate. International Journal of Hospitality Management, 55, 41-51.

Kim, M. R., Vogt, C. A., \& Knutson, B. J. (2013). Relationships among customer satisfaction, delight, and loyalty in the hospitality industry. Journal of Hospitality $\mathcal{E}$ Tourism Research, 39(2), 170197.

Kim, Y. K., \& Lee, H. R. (2011). Customer satisfaction using low cost carriers. Tourism Management, 32(2), 235-243.

Kos Koklic, M., Kukar-Kinney, M., \& Vegelj, S. (2017). An investigation of customer satisfaction with low-cost and full-service airline companies. Journal of Business Research, 80, 188-196.

Kudeshia, C., \& Kumar, A. (2017). Social eWOM: Does it affect the brand attitude and purchase intention of brands?. Management Research Review, 40(3), 310-330.

Lacic, E., Kowald, D., \& Lex, E. (2016). High Enough? Explaining and Predicting Traveler Satisfaction Using Airline Reviews. Paper presented at 27th ACM Conference on Hypertext and Social Media, 10-13th July 2016, Halifax, Nova Scotia, Canada.

Lee, J., Park. D., \& Han, I. (2011). The different effects of online consumer reviews on consumers' purchase intentions depending on trust in online shopping malls: an advertising perspective. Internet Research, 21(2), 187-206.

Leong, L., Hew, T., Lee, V., \& Ooi, K. (2015). An SEM-artificial-neural-network analysis of the relationships between SERVPERF, customer satisfaction and loyalty among low-cost and full-service airline. Expert Systems with Applications, 42(19), 6620-6634.

Lin, H., \& Huang, Y. (2015). Factors affecting passenger choice of low cost carriers: an analytic network process approach. Tourism Management Perspectives, 16, 1-10.

Lin, C., Lee, S., \& Horng, D. (2011). The effects of online reviews on purchasing intention: the moderating role of need for cognition. Social Behavior and Personality: An International Journal, 39(1), 71-81.

Liu, C., Guo, Y. M., \& Lee, C. (2011). The effects of relationship quality and switching barriers on customer loyalty. International Journal of Information Management, 31, 71-79.

Mellinas, J. P., Nicolau, J. I., \& Park, S. (2019). Inconsistent behavior in online consumer reviews: the effects of hotel attribute ratings on location. Tourism Management, 71, 421-427.

Milioti, C. P., Karlaftis, M. G., \& Akkogiounoglou, E. (2015). Traveler perceptions and airline choice: a multivariate probit approach. Journal of Air Transport Management, 49, 46-52.

Min, H., Lim, Y., \& Magnini, V. P. (2014). Factors affecting customer satisfaction in responses to negative online hotel reviews. Cornell Hospitality Quarterly, 56(2), 223-231.

Mohsan, F., Nawa, N. M., Khan, S., Shaukat, Z., \& Aslam, N. (2011). Impact of customer satisfaction on customer loyalty and intentions to switch: evidence from banking sector of Pakistan. International Journal of Business and Social Science, 2(16), 265-268.

Nadiri, H., Hussain, K., Ekiz, E. H., \& Erdoğan, Ş. (2008). An investigation on the factors influencing passengers' loyalty in the North Cyprus National Airline. The TQM Journal, 20(3), 265-280. 
Namukasa, J. (2013). The influence of airline service quality on passenger satisfaction and loyalty: the case of Uganda airline industry. The TQM Journal, 25(5), 520-532.

Neirotti, P., Raguseo, E., \& Paolucci, E. (2016). Are Customers' reviews creating value in the hospitality industry? exploring the moderating effects of market positioning. International Journal of Information Management, 36, 1133-1143.

$\mathrm{Ng}$, S. I., Sambasivan, M., \& Zubaidah, S. (2011). Antecedents and outcomes of flight attendants' job satisfaction. Journal of Air Transport Management, 17(5), 309-313.

Noyan, F., \& Gölbaşı Şimşek, G. (2014). The antecedents of customer loyalty. Procedia - Social and Behavioral Sciences, 109, 1220-1224.

Nyadzayo, M. W., \& Khajehzadeh, S. (2016). The antecedents of customer loyalty: a moderated mediation model of customer relationship management quality and brand image. Journal of Retailing and Consumer Services, 30, 262-270.

Ostrowski, P. L., O’Brien, T. V., \& Gordon, G. L. (1993). Service quality and customer loyalty in the commercial airline industry. Journal of Travel Research, 32, 16-24.

Pacheco, L. (2016). An analysis of online reviews by language groups: the case of hotels in Porto, Portugal. European Journal of Tourism Research, 14, 66-74.

Pakdil, F., \& Aydın, Ö. (2007). Expectations and perceptions in airline services: an analysis using weighted SERVQUAL scores.Journal of Air Transport Management, 13, 229-37.

Pan, Y., Sheng, S., \& Xie, F. T. (2012). Antecedents of customer loyalty: an empirical synthesis and reexamination. Journal of Retailing and Consumer Services, 19, 150-158.

Parasuraman, A., Zeithaml, V.A., \& Berry, L. L. (1991). Refinement and reassessment of SERVQUAL scale. Journal of Retailing, 67, 420-450.

Parasuraman, A., Zeithaml, V. A., \& Berry, L. L. (1994a). Reassessment of expectations as a comparison in measuring service quality: implications for further research. Journal of Marketing, 58(1), 111-124.

Parasuraman, A., Zeithaml, V. A., \& Berry, L. L. (1994b). Alternative scales for measuring service quality: a comparative assessment based on psychometric and diagnostic criteria. Journal of Retailing, 70(3), 201-230.

Park, S., \& Nicolau, J. L. (2015). Asymmetric effects of online consumer reviews. Annals of Tourism Research, 50, 67-83.

Park, H. (2013). An introduction to logistic regression: from basic concepts to interpretation with particular attention to nursing domain. Journal of Korean Academyc of Nursing, 43(2), 154-164.

Park, J., Robertson, R., \& Wu, C. (2004). The effect of airline service quality on passengers' behavioural intentions: A Korean case study. Journal of Air Transport Management, 10, 435439.

Phillips, P., Antonio, N., de Almedia, A., \& Nunes, L. (2020). The influence of geographic and psychic distance on online hotel ratings. Journal of Travel Research, 59(4), 722-741.

Raguseo, E., Neirotti, P., \& Paolucci, E. (2017). How small hotels can drive value their way in infomediation: The case of 'Italian Hotels vs. OTAs and TripAdvisor'. Information $\mathcal{E}$ Management, 54(6), 745-756.

Rahman, M. A., \& Ramli, M. F. (2016). The influence of relationship quality on customer loyalty in the dual-banking system in the northern states of peninsular Malaysia. Procedia-Social and Behavioral Sciences, 219, 606-613.

Rose, M., \& Blodgett, J. G. (2016). Are management responses to negative online consumer reviews beneficial?, Looking forward, looking back: drawing on the past to shape the future of marketing. In C. Campbell, \& J. Ma (Eds.), Developments in Marketing Science: Proceedings of the Academy of Marketing Science (pp. 788-791). Cham: Springer.

Sarkar, S. K., \& Midi, H. (2010). Importance of assessing the model adequacy of binary logistic regression. Journal of Applied Sciences, 10(6), 479-486.

Schuckert, M., Lie, X., \& Law, R. (2016). Insights into suspicious online ratings: direct evidence from TripAdvisor. Asia Pacific Journal of Tourism Research, 21(3), 259-272.

Shah, F. T., Syed, Z., Imam, A., \& Raza, A. (2020). The impact of airline service quality on passengers' behavioral intentions using passenger satisfaction as a mediator. Journal of Air Transport Management, 85, 101815. 
Siering, M., Deokar, A. V., \& Janze, C. (2018a). Disentangling consumer recommendations: explaining and predicting airline recommendations based on online reviews. Decision Support Systems, 107, 52-63.

Siering, M., Muntermann, J., \& Rajagopalan, B. (2018b). Explaining and predicting online review helpfulness: the role of content and reviewer-related signals. Decision Support Systems, 108, 1-12.

Sparks, B. A., Fung-So, K. K., \& Bradley, G. L. (2016). Responding to negative online reviews: the effects of hotel responses on customer inferences of trust and concern. Tourism Management, 53, 74-85.

Srivastava, M., \& Kaul, D. (2016). Exploring the link between customer experience-loyalty-consumer spend. Journal of Retailing and Consumer Services, 31, 277-286.

Stamolampros, P., Korfiatis, N., Kourouthanassis, P., \& Symitsi, E. (2018). Flying to quality: cultural influences on online reviews. Journal of Travel Research, 58(3), 496-511.

Stringam, B. B., \& Gerdes, J. (2010). An analysis of word-of-mouse ratings and guest comments of online hotel distribution sites. Journal of Hospitality Marketing $\mathcal{E}$ Management, 19(7), 773-796.

Stringam, B. B., Gerdes, J., \& Vanleeuwen, D. M. (2010). Assessing the importance and relationships of ratings on user-generated traveler reviews. Journal of Quality Assurance in Hospitality $\mathcal{E}$ Tourism, 11(2), 73-92.

Suki, N. M. (2014). Passenger satisfaction with airline service quality in Malaysia: A structural equation modeling approach. Research in Transportation Business \& Management, 10, 26-32.

Taştan, H., \& Kızılcık, O. (2017). Classification of shared complaints on Tripadvisor.com for food and beverage businesses in Kahramanmaraş. Çukurova University, Journal of Social Sciences Institute, 26(1), 270-284.

Tessema Zewude, B., \& Meskele Ashine, K. (2016). Binary logistic regression analysis in assessment and identifying factors that influence students' academic achievement: the case of college of natural and computational science, Wolaita Sodo University, Ethiopia. Journal of Education and Practice, 7(5), 3-7.

Thomas, M., Wirtz, B. W., \& Weyerer, J. C. (2019). Determinants of online review credibility and its impact on consumers' purchase intention. Journal of Electronic Commerce Research, 20(1), 120.

Thuy Tran, L. T., Minh Ly., P. T., \& Tuan Le, L. (2019a). Hotel choice: a closer look at demographics and online ratings. International Journal of Hospitality Management, 82, 13-21.

Thuy Tran, L. T., Minh Ly., P. T., \& Tuan Le, L. (2019b). E-satisfaction and continuance intention: the moderator role of online ratings. International Journal of Hospitality Management, 77, 311-322.

Truitt, L., \& Haynes, R. (1994). Evaluating Service quality and productivity in the regional airline industry. Transportation Journal, 33, 21-32.

Vlachos, I., \& Lin, Z. (2014). Drivers of airline loyalty: evidence from the business travelers in China. Transportation Research Part E, 71, 1-17.

Wan Daud, W. N., Haron, H., \& Ibrahim, D. N. (2011). The role of quality board of directors in enterprise risk management (ERM) practices: evidence from binary logistic regression. International Journal of Business and Management, 6(12), 205-211.

Wang, R., Hsu, S., Lin, Y. H., \& Tseng, M. (2011). Evaluation of customer perceptions on airline service quality in uncertainty. Procedia: Social and Behavioral Sciences, 25, 419-437.

We Are Social. (2020). Digital in 2020. Retrieved in October 27, 2020, from https://wearesocial.com/global-digital-report-2020.

World Airline Awards. (2020). About the World Airline Awards. Retrieved in July 23, 2020, from https://www.worldairlineawards.com/about-us.

World Airline Awards. (2019). World's Top 100 Airlines 2019. Retrieved in October 7, 2019, from https://www.worldairlineawards.com/worlds-top-100-airlines-2019.

$\mathrm{Wu}, \mathrm{H}$. , \& Cheng, C. (2013). A hierarchical model of service quality in the airline industry. Journal of Hospitality and Tourism Management, 20, 13-22.

Xie, K. L., Fung-So, K. K., \& Wang, W. (2017). Joint effects of management responses and online reviews on hotel financial performance: a data-analytics approach. International Journal of Hospitality Management, 62, 101-110. 
Yao, B., Yuan, H., Qian, Y., \& Li, L. (2015). On exploring airline service features from massive online review. Paper presented at the 12th International Conference on Service Systems and Service Management (ICSSSM), 22nd-24th June 2015, Guangzhou, China.

Zaidan, E. (2017). Analysis of ICT usage patterns, benefits and barriers in tourism SMEs in the Middle Eastern countries: the case of Dubai in UAE. Journal of Vacation Marketing, 23(3), 248-263.

Zakaria, I., Rahman, B. A., Othman, A. K., Mohamed Yunus, N. A., Dzulkipli, M. E., \& Faiz Ozman, M. A. (2014). The relationship between loyalty program, customer satisfaction and customer loyalty in retail industry: a case study. Procedia - Social and Behavioral Sciences, 129, 23-30.

Zhang, K. Z. K., Zhao, S. J., Cheung, C. M. K., \& Lee, M. K. O. (2014). Examining the influence of online reviews on consumers' decision-making: a heuristic-systematic model. Decision Support Systems, 67, 78-89.

Zhang, H., Han, X., \& Dai, S. (2013). Fire occurrence probability mapping of Northeast China with binary logistic regression model. IEEE Journal of Selected Topics in Applied Earth Observations and Remote Sensing, 6(1), 121-127.

Zhu, L., Lin, Y., \& Cheng, M. (2019). Sentiment and guest satisfaction with peer-to-peer accommodation: when are online ratings more trustworthy?. International Journal of Hospitality Management, 86, 1023692.

Zhu, D. H., Zhang, Z. J., Chang, Y. P., \& Liang, S. (2018). Good discounts earn good reviews in return? effects of price promotion on online restaurant reviews. International Journal of Hospitality Management, 77, 178-186. 